УДК 316.464

O. М. Аебедъ, здобувач магістратури каредри управління охороною здоров' я та публічного адміністрування, Начіональний університет охорони здоров' я Украӥни імені П. А. Шупика ORCID ID: 0000-0002-1386-3951

3. В. Гбур,

д. держ. упр., професор кафедри управління охороною здоров' я та публічного адміністрування, Начіональний університет охорони здоров' я Украӥни імені П. А. Шупика

ORCID ID: 0000-0003-4536-2438

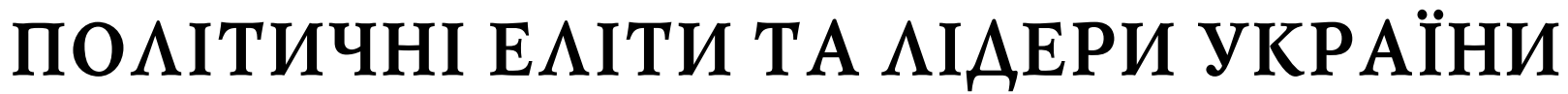

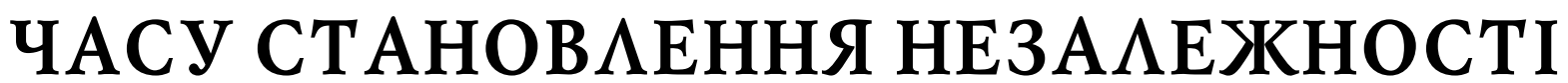

\author{
O. Lebed, \\ Master's student of the Department of Management health care and public administration, \\ Shupyk National Healthcare University of Ukraine, Kyiv, Ukraine \\ Z. Hbur, \\ Doctor of Sciences in Public Administration, Full Professor, Professor of the Department of Healthcare Management \\ and Public Administration, Shupyk National Healthcare University of Ukraine, Kyiv, Ukraine
}

\section{POLITICAL ELITE AND LEADERS OF UKRAINE DURING INDEPENDENCE}

У статті досліджувалися політичні еліти та лідери України часу становлення незалежності. Зокрема, визначено наукову позицію стосовнодефініції "політична еліта" та "політичний лідер". Встановлено перелік ознак, які характеризують певну групу осіб як політичну еліту, до яких належить: організована група людей, лідери соціальної ієрархії, здатність впливати на управлінський процес, організовують та сконцентровують у своїх руках політичну владу. Визначено перелік Функцій, які уповноважена виконувати політична еліта. Досліджено історичний шлях формування та Функціонування політичної еліти та політичних лідерів протягом часу, починаючи з проголошення незалежності України і до сучасності. Українає молодою державою, яка вчиться жити самостійно. Відповідно політична система України не набула стабільного становища та визначеного курсу свого розвитку. Для розуміння сутності категорії "політична еліта", яка є суб'єктом політичної влади необхідно визначити її поняття. Встановлено, що еволюція політичної еліти та політичних лідерів пройшла шість етапів та перебуває на сьомому, який почався 32019 року. Досліджено портрет Верховної Ради України всіх скликань та визначено особливості їх формування, де чітко простежується його депутатське перезавантаження, гендерна різноманіть, омолодження складу Верховної Ради України та набуття статусу народного депутата України особами, які раніше були депутатами різних рівнів. Визначено ступінь оцінки суспільством діючої влади, яка відображається в балансі довіри і недовіри та критерії такої оцінки. Встановлено проблеми української політичної еліти та лідерів, які впливають на ефективність їх діяльності. Визначено позитивні та негативні характерні риси, які притаманні політичним елітам та лідерам з початку незалежності України і до сьогодні, які грунтувалися на основі усталеної практики формування політичної еліти та лідерів протягом досліджуваного періоду. Також Функціонування, діяльність політичних еліт та лідерів та їх оцінка надана суспільством. Встановлено, що проблеми політичної еліти набувають глобальнішого характеру та визначених форм. 
The article examines the political elites and leaders of Ukraine since independence. In particular, a scientific position on the definition of "political elite" and "political leader" has been defined. A list of characteristics that characterize a certain group of people as a political elite, which includes: an organized group of people, leaders of the social hierarchy, the ability to influence the management process, organize and concentrate political power in their hands. The list of functions that the political elite is authorized to perform is defined. The historical way of formation and functioning of the political elite and political leaders over time, from the proclamation of Ukraine's independence to the present, is studied. Ukraine is a young country that is learning to live independently. Accordingly, the political system of Ukraine has not acquired a stable position and a certain course of its development. To understand the essence of the category "political elite", which is the subject of political power, it is necessary to define its concept. It is established that the evolution of the political elite and political leaders has gone through six stages and is in the seventh, which began in 2019. The portrait of the Verkhovna Rada of Ukraine of all convocations is studied and the peculiarities of their formation are determined, where its parliamentary reset, gender diversity, rejuvenation of the Verkhovna Rada of Ukraine and acquisition of the status of People's Deputy of Ukraine by persons who were former deputies of different levels are clearly traced. The degree of society's assessment of the current government is determined, which is reflected in the balance of trust and distrust and the criteria for such assessment. The problems of the Ukrainian political elite and leaders that affect the effectiveness of their activities have been identified. The positive and negative characteristics of political elites and leaders from the beginning of Ukraine's independence to the present day, which were based on the well-established practice of forming political elites and leaders during the period under study, have been identified. Also, the functioning, activities of political elites and leaders and their evaluation are provided by society. It is established that the problems of the political elite become more global and take certain forms.

Ключові слова: політична Влада, президент, уряд, Верховна Рада України, політики, політичний клас, державне управління.

Key words: political power, president, government, Verkhovna Rada of Ukraine, politicians, political class, public administration.

\section{ПОСТАНОВКА ПРОБАЕМИ}

Становлення української державності пройшло довгий шлях іï фрормування. Незалежною Україна стала зовсім недавно відносно сталості формування суспільно-політичної свідомості. Донедавна свідоме покоління українського народу жило в тоталітарних умовах та підкорялися радянській владі. Історія зробила справжній подарунок українському народу, який полягав у можливості фрормувати державну владу та визначати політичну еліту та лідера самостійно, керуючись власними інтересами та визначаючи політичні цілі. Тому доцільно дослідити еволюцію фрормування та результати діяльності політичної еліти та лідерів за весь період незалежності України.

\section{АНА $\Lambda$ I ОСТ АHНIX АОС IАЖЕНЬ ТА ПУБАІКАЦІЙ}

Теоретичною основою дослідження поняття "політична еліта" та "політичний лідер" є наукові праці: Очирова В.М., Мораря М.В., Higley J., Garrido-Vergara L. Функції політичної еліти досліджували: Очирова В.М., Крючков В.А., Сковиков А.К., Титова О.Н., Щедрова Г.П. Історичні та теоретичні аспекти фрормування політичної еліти та лідера в Україні досліджували: Кобець Ю., Висоцький В.М., Федоров М., Антонова Н.Б., Захарова Л.М., Вечер Л.С., Кобець Ю.В., Мандзій Л.С., Бойко С., Горбач Д., Корнієнко В.О. та інші.

\section{META CTATTI}

Метою статті $€$ визначення позитивних та негативних рис формування політичної еліти та лідерів України протягом часу становлення незалежності.

\section{ВИК ААА ОСНОВНОГО МАТЕРІААУ АОС $А$ АЖЕННЯ}

Історичний досвід та сучасна практика свідчать, що відбутися як політична нація може лише соціально розвинений народ, що має власну провідну верству, життєздатну еліту [5, с. 73].

Україна $є$ молодою державою, яка вчиться жити самостійно. Відповідно політична система України не набула стабільного становища та визначеного курсу свого розвитку. Для розуміння сутності категорії "політична еліта", яка є суб'єктом політичної влади необхідно визначити її поняття. В науці "політичну еліту" визначають:

- група людей, корпорацій, політичних партій та / або будь-якого іншого роду організацій громадянського суспільства, які керують і організовують управління та всі прояви політичної влади [16, с. 33];

- особи, які в силу свого стратегічного розташування у великих або інших організаціях і рухах, здатні регулярно та суттєво впливати на політичні результати $[17$, с. 3].

- нечисленну групу осіб, що знаходяться на вершині соціальної ієрархії, яка професійно зай- 
Таблиця 1. Історичні етапи формування політичної еліти в Україні

\begin{tabular}{|c|c|}
\hline \begin{tabular}{|l} 
І етап \\
(1991-1994 pp.)
\end{tabular} & $\begin{array}{l}\text { Створюється основа політичної еліти країни. Кількісно та якісно в ії складі домінує номенклатура, що } \\
\text { відмовилася від комуністичної ідеології й узяла на озброєння ідею національно-державного будівництва та } \\
\text { незалежності України. Перші кроки в цьому напрямі - це ліквідація монополії формування державної } \\
\text { політики з боку КПРС через скасування ст. } 6 \text { Конституції УРСР. Історичними здобутками цього етапу є } \\
\text { запровадження демократичних інститутів влади - парламентаризму й інституту президентства; створення } \\
\text { умов для появи багатопартійності як інституту громадянського суспільства; зародження засад місцевого } \\
\text { самоврядування; зародження та розвиток конституційного процесу. Правовим підгрунтям діяльності } \\
\text { політичних партій на цьому етапі стали Конституція (Основний Закон) УРСР (1978 р.) та Закон «Про } \\
\text { об’єднання громадян» (1992 р.) }\end{array}$ \\
\hline $\begin{array}{l}\text { IV етап } \\
\text { (2004-2013 pp.) }\end{array}$ & $\begin{array}{l}\text { Псевдо зміна політичної еліти часів Помаранчевої революції спричинила початок їі глибокої деформації. } \\
\text { Характерними для політичної еліти в п’ятирічку «помаранчевої» влади стали відносно низький рівень } \\
\text { професіоналізму значної їі частини; відсутність необхідного стратегічного мислення; низька ефективність і } \\
\text { якість прийнятих політичних рішень; невміння домовлятися, погоджувати інтереси, доходити до } \\
\text { політичних компромісів і в зовнішній, і у внутрішній політиці; відчуження від суспільства, що призвело до } \\
\text { поглиблення соціального розриву між ії представниками й пересічними громадянами. Залучення в складі } \\
\text { політичної еліти представників бізнесових структур, особисті інтереси яких домінували над інтересами } \\
\text { суспільства. Запровадження пропорційної системи виборів до Верховної Ради України та більшості органів } \\
\text { місцевого самоврядування й ухвалення } 8 \text { грудня } 2004 \text { р. Закону України № 2222-ІУ «Про внесення змін до } \\
\text { Конституції України». У результаті конституційних і законодавчих змін, політичні партії стали єдиним } \\
\text { механізмом формування парламенту та більшості органів місцевого самоврядування, одержали } \\
\text { максимальні можливості для реалізації власних політичних програм на загальноукраїнському та місцевому } \\
\text { рівнях. Конституційні зміни надали потужний імпульс для трансформації української політичної системи } \\
\text { від президентсько-парламентської до парламентарнопрезидентської системи. Зі скасуванням } 30 \text { вересня } \\
\text { 2010 р. Конституційним Судом України конституційної реформи } 2004 \text { р., країна повернулася до } \\
\text { Конституції зразка 1996 р., а політична система країни - до президентсько-парламентського формату. } \\
\text { Отже, Україна, рухаючись у бік парламентаризованих форм державного правління, зробила радикальний } \\
\text { крок у зворотному напрямку, тобто на користь президентської форми державного правління } 32013 \text { року } \\
\text { відбувається болісний процес зміни вікових поколінь та зміна професійного і гендерного складу еліт }\end{array}$ \\
\hline $\begin{array}{l}\text { V етап } \\
\text { (2014-2019 pp.) }\end{array}$ & $\begin{array}{l}\text { У } 2014 \text { році закінчилася Революція Гідності, яка продемонструвала місце суспільства у формуванні } \\
\text { політичної еліти та відповідно відбулося її оновлення у екстремальних умовах в надзвичайно стислий } \\
\text { термін. } 32014 \text { р. повернулася у дію Конституція України в редакції } 2004 \text { р., а отже, і парламентсько- } \\
\text { президентської форми правління. Сучасну політико-правову ситуацію можна розглядати як своєрідну } \\
\text { паузу, яка дає змогу розвести в часі вирішення питань забезпечення дієздатності політичної системи } \\
\text { України. Конституція } 2004 \text { р. може стати тією політикоправовою моделлю, від якої слід відштовхуватися } \\
\text { під час модернізації політичної системи країни }\end{array}$ \\
\hline $\begin{array}{l}\text { VI етап } \\
\text { (2019 рік і до } \\
\text { сьогодні) }\end{array}$ & $\begin{array}{l}\text { Відзначився повним перезавантаженням складу політичної еліти, яка вперше в історії України утворила } \\
\text { монополію політичної влади, так як Президент України, більшість Верховної Ради України та Уряд } \\
\text { належать до однієї політичної сили }\end{array}$ \\
\hline
\end{tabular}

Джерело: розробка авторів на основі [3; 5].

мається діяльністю в сорері влади і управління державою (партіями, іншими політичними інститутами), яка концентрує у своїх руках значний обсяг політичної влади і приймає стратегічні рішення загальнодержавного рівня (або може впливати на цей процес) [11, с. 72].

Отже, аналізуючи зазначені вище десрініції, можна виділити основні ознаки, які характерні політичній еліті:

- організована група людей;

- лідери соціальної ієрархії;

- здатність впливати на управлінський процес;

- організовують та сконцентровують у своїх руках політичну владу.
Політична еліта $є$ визначеним колом людей, які обрані певними особами задля здійснення впливу на побудову та фрункціонування політичної системи. Так, найважливішими фуннкціями політичної еліти в сфері управління державою і суспільством є:

- стратегічна (визначення основних напрямів державної політики, що відображають інтереси різних соціальних груп і всього суспільства загалом);

- організаторська (здійснення на практиці виробленого державного курсу, втілення політичних рішень у життя);

- інтеграційна (зміцнення стабільності та єдності суспільства, стійкості його політичної та економічної си- 
Таблиця 2. Портрет Верховної Ради України всіх скликань

\begin{tabular}{|c|c|c|c|c|}
\hline Скликання ВР & $\begin{array}{c}\text { Середній } \\
\text { вік }\end{array}$ & $\begin{array}{c}\text { Топ-професії до } \\
\text { депутатства }\end{array}$ & \begin{tabular}{|c|} 
Частка \\
депутатів 3 \\
вищої \\
освіти \\
\end{tabular} & $\begin{array}{c}\text { Гендерний } \\
\text { баланс }\end{array}$ \\
\hline I (1990-1994 pp.) & 47 & $\begin{array}{l}\text { Інженер - } 39 \% \\
\text { Вчений-агроном -12\% } \\
\text { Лікар - } 4 \text { \% }\end{array}$ & $95,8 \%$ & $\begin{array}{l}\text { Чоловіки - } 97 \text { \% } \\
\text { Жінки - } 3 \%\end{array}$ \\
\hline II (1994-1998 pp.) & 46 & $\begin{array}{l}\text { Інженер - } 31 \% \\
\text { Вчитель - } 11 \% \\
\text { Економіст - } 11 \%\end{array}$ & $94 \%$ & $\begin{array}{l}\text { Чоловіки - } 96 \% \\
\text { Жінки - } 4 \%\end{array}$ \\
\hline III (1998-2002 pp.) & 47 & $\begin{array}{l}\text { Інженер - } 31 \% \\
\text { Економіст - } 11 \% \\
\text { Юрист - } 8 \%\end{array}$ & $96 \%$ & $\begin{array}{l}\text { Чоловіки - } 92 \% \\
\text { Жінки - } 8 \%\end{array}$ \\
\hline IV (2002-2006 pp.) & 49 & $\begin{array}{l}\text { Інженер - } 31 \% \\
\text { Економіст - } 11 \% \\
\text { Юрист - } 8 \%\end{array}$ & $99 \%$ & $\begin{array}{l}\text { Чоловіки - } 94 \text { \% } \\
\text { Жінки - } 6 \%\end{array}$ \\
\hline V (2006-2007 pp.) & 49 & Немає даних & $99 \%$ & $\begin{array}{l}\text { Чоловіки - } 91 \% \\
\text { Жінки - 9\% }\end{array}$ \\
\hline VI (2007-2012 pp.) & 48 & Немає даних & $99 \%$ & $\begin{array}{l}\text { Чоловіки - 92 \% } \\
\text { Жінки - } 8 \%\end{array}$ \\
\hline VII (2012-2014 pp.) & 48 & Немає даних & $99 \%$ & $\begin{array}{l}\text { Чоловіки - } 90 \% \\
\text { Жінки - } 10 \%\end{array}$ \\
\hline VIII (2014-2019 pp.) & 44 & $\begin{array}{l}\text { Народний } \\
\text { депутат - 34\% } \\
\text { Керівник - } 24 \text { \% } \\
\text { Тимчасово } \\
\text { непрацюючий - } 8 \text { \% }\end{array}$ & $97 \%$ & $\begin{array}{l}\text { Чоловіки - } 88 \% \\
\text { Жінки - } 12 \%\end{array}$ \\
\hline $\begin{array}{l}\text { IX (2019 p. - } \\
\text { до тепер) }\end{array}$ & 41 & $\begin{array}{l}\text { Депутати - } 82 \text { \% } \\
\text { Безробітні - } 7 \text { \% }\end{array}$ & $91,3 \%$ & $\begin{array}{l}\text { Чоловіки - 79,2 \% } \\
\text { Жінки - 20,8 \% }\end{array}$ \\
\hline
\end{tabular}

Джерело: [7].

стем, профрілактика і вирішення конфрліктних ситуацій) та ін. [11, с.72].

В.А. Крючков та інші відзначають, що політична еліта в сучасному суспільстві виконує надзвичайно широкі функції, класифікація яких здійснюється за різними підставами: суб'єктами, сорерами діяльності, визначеними цілям. Залежно від характеру пануючого суб'єкта виділяються такі фрункції: панування, підпорядкування, мобілізація, інтеграція. У різних сорерах політичні суб'єкти можуть виконувати економічну, соціальну або соціокультурну функцію, беручи участь у контролі над власністю, розподілі матеріальних благ для членів соціуму, виробництві і розповсюдженні цінностей, ідей, норм. Політична еліта концентрується в політичних інститутах, розподіляючись по горизонталі і вертикалі влади, причому на початку становлення вона фрормується як політичне лідерство, потім відбувається фрормування політичної еліти, виділяється політичний клас і правлячий клас, з'являються регіональні і місцеві (міські) еліти. Становлення політичної еліти - це механізм рекрутування, тобто включення до складу еліти нових суб'єктів, який може бути відкритим і закритим, здійснюватися різними способами в залежності від типу політичного режиму. Формування нової політичної еліти відбувається тоді, коли змінюється соціальна структура суспільства, з'являються нові групи інтересів, нові політичні інститути і політичні суб'єкти. До таких суб'єктів впливу на різних етапах суспільного буття могли належати: військова еліта, економічна еліта, інтелектуальна еліта [8, с. 1738].

Для повноцінної реалізації вказаних функцій політична еліта має бути носієм відповідного набору рис і якостей. Серед таких основними є високий рівень адаптивності, відповідальність і здатність до аналізу та про- гнозування наслідків ухвалених управлінських рішень, дипломатичність, далекоглядність і компромісність у питаннях пошуку суспільного консенсусу [15, с. 239].

Особливості функціонування політичної еліти в Україні виділив М. Федоров, який відзначив, що українській політичній еліті характерна самостійність відносно до суспільства, виражена групова свідомість, поділ на владу та опозицію з різними в часі частками стосовно суспільних впливів, визначене коло цілей та інтересів конкретних осіб, усталений погляд на створену групу як на "касту обраних", що відповідно до українського менталітету іноді набуває ознак "нарцисизму" [13, c. 20].

Повною мірою погоджуємося з М. Федоровим, така позиція обгрунтовується історичним минулим фрормування політичної еліти з часів отримання незалежності Україною та створення її власної політичної еліти, яка була обрана лише українським суспільством.

За період самостійності України вітчизняна політична система набула істотних змін, що полягали в переході від директивної комуністичної ідеології, політико-державного моноцентризму до визнання на конституційному рівні реальної багатопартійності та свободи політичної діяльності, до цілком реального впливу політичних партій на формування державної влади [3, с. 3-5].

Утворення політичної еліти після проголошення незалежності України, не могло призвести до корінних змін її складу. Таке становище було зумовлено неготовністю населення до самостійного формування органів державної влади. Громадяни України традиційно жили у тоталітарному режимі, тому демократичні засади державного управління для них були зовсім новими.

Найважливішими особливостями першого етапу еволюції правлячої політичної еліти є: несамостійність, 
Таблиця 3. Оцінка громадянами діяльності влади, рівень довіри до соціальних інститутів та політиків у вересні 2019 року та лютий 2020 року

\begin{tabular}{|l|l|l|l|l|l|l|l|l|l|l|l|l|}
\hline & \multicolumn{2}{|c|}{$\begin{array}{c}\text { Зовсім } \\
\text { не довіряю }\end{array}$} & \multicolumn{2}{|c|}{$\begin{array}{c}\text { Скоріше } \\
\text { не довіряю }\end{array}$} & \multicolumn{2}{|c|}{$\begin{array}{c}\text { Скоріше } \\
\text { довіряю }\end{array}$} & \multicolumn{2}{|c|}{$\begin{array}{c}\text { Повністю } \\
\text { довіряю }\end{array}$} & \multicolumn{2}{|c|}{$\begin{array}{c}\text { Важко } \\
\text { відповісти }\end{array}$} & \multicolumn{2}{c|}{$\begin{array}{c}\text { Баланс } \\
\text { довіри- } \\
\text { недовіри }\end{array}$} \\
\hline & 2019 & 2020 & 2019 & 2020 & 2019 & 2020 & 2019 & 2020 & 2019 & 2020 & 2019 & 2020 \\
\hline $\begin{array}{l}\text { Президент } \\
\text { України }\end{array}$ & 4,1 & 17,9 & 9,4 & 22,7 & 48,9 & 39,5 & 30,5 & 12.0 & 7,2 & 8.0 & 65,9 & 10,9 \\
\hline $\begin{array}{l}\text { Верховна Рада } \\
\text { України }\end{array}$ & 6 & 28,1 & 19,1 & 36,9 & 43,4 & 24,6 & 13,3 & 3,3 & 18,2 & 7,2 & 31,6 & $-37,1$ \\
\hline Уряд України & 6,2 & 27,7 & 15,6 & 36,8 & 44,8 & 24,4 & 12,1 & 3,6 & 21,3 & 7,5 & 35,1 & $-36,5$ \\
\hline
\end{tabular}

Джерело: розробка автора на основі [14].

регіональність, виконавча сутність правлячої політичної еліти, домінування в її трансорормаціях тенденцій наступності; процес зміни поколінь; загострений вияв нестачі "внутрішніх" резервів, практично повна відсутність можливості рекрутування членів правлячої політичної еліти із зовні, неподолані правлячою політичною елітою численні перешкоди на шляху до свого самодостатнього розвитку, існування певного "пакту". Правляча політична еліта набула ознак консолідованої: вона поєднала представників колишньої влади та колишньої опозиції на основі ідеї незалежності та виживання у системі і витіснила радикальні частини двох колишніх таборів [9, с. 11].

Так, Верховна Рада ІІ скликання, яка функціонувала з 1994 по 1998 роки оновлювалась найбільше - на $85 \%$. Це означає, що 85\% народних депутатів ІІ скликання не були у складі Верховної Ради України попереднього скликання. Можливо, такий показник пояснюється розпадом СРСР та незалежністю України, оскільки II скликання було першим після цих подій, і таким чином виборці реалізували своє прагнення до нових облич. Водночас найменше оновлення парламенту відбулося у VI скликанні - 36\%. Можливо, це тому, що депутати попереднього скликання реалізовували свої повноваження лише півтора року і за цей час не встигли розчарувати своїх виборців [7]. Нинішній склад Верховної Ради України оновився на $80 \%$, таке становище зумовлено суспільною позицією, яка мала за мету переламати усталену політичну систему, що складалася 3 політичної бізнес еліти та сорормувати новий парламент з амбітною молоддю, яка здійснить ряд вдалих реформ відповідно до викликів сучасності та покращить соціально-економічне становище держави (табл. 2).

Аналізуючи показники таблиці 3, вбачається, що політична еліта порівняно зі складом Верховної Ради України всіх скликань складається зі значно молодшого складу народних депутатів, які в меншій кількості мають вищу освіту та $82 \%$ їх до набуття статусу народного депутата України займалися депутатською діяльністю, в більшості на місцях. Тому можна зробити висновок, що місцева політична еліта отримала високу оцінку своєї діяльності і, як наслідок, була обрана у Верховну Раду України.

Отже, в залежності від реалізації суспільних інтересів тієї групи осіб, які їх обрали, а також ефективності реалізації їх функції як політичної еліти, що уособлює політичну владу отримують відповідну суспільну оцінку. Така оцінка $є$ важливою, бо демонструє рівень довіри людей до діючої влади та є латексною смужкою, яка визначає їх суспільний настрій. Так, спостерігаєть- ся динаміка суспільної оцінки роботи нинішньої влади на початку їх діяльності та через пів року (табл. 3).

Вдало відзначає Н.Б. Антонова, що під час оцінювання ефективності державного управлінні мають порівнюватись, як мінімум:

- цілі, які реалізовані в управлінських процесах, 3 результатами одержаними при об'єктивізації державного управління (рішень і дій його управлінських компонентів);

- цілі, які практично реалізуються в ньому, з цілями, які об'єктивно детерміновані суспільними запитами;

- суспільні витрати, які пішли на державне управління, з об'єктивними результатами, одержаними внаслідок управління;

- реальні результати управління із суспільними інтересами і потребами;

- можливості, закладені в управлінському потенціалі, зі ступенем їх реального використання [1, с. 219].

Аналізуючи суспільну оцінку політичної влади, яка функціонує на даний час, вбачаємо, що рівень довіри громадян, за невеликий період для державного управління, значно понизився: до Президента України баланс довіри-недовіри понизився з 65,9 у 2019 році до 10,9 у 2020 році, до Верховної Ради України - з 31,6 у 2019 році до - 37,1 у 2020 році та до Уряду від 35, 1 у 2019 році до - 36,5 у 2020 році.

Тому можна зробити висновок, що очікування суспільства від новообраної політичної еліти покращення соціально-економічного становища держави не виправдались.

Політичними лідерами в науці визначають людей, які мають бути професійно, інтелектуально, морально-психологічно та організаційно підготовлені до владної діяльності, спроможні справляти легітимний вплив на все суспільство або його частину. Політичним лідером $€$ особа, яка здатна консолідувати громадян навколо спільної мети, застосовуючи виключно легітимні засоби впливу на політичну свідомість та поведінку певних соціальних груп, спираючись на свій професіійний і особистий авторитет. Політичне лідерство - це суспільно-політичний процес, коли одна особа або група авторитетних осіб представляють інтереси і сподівання широких народних мас та пропонують шляхи їх реалізації [10, с. 6-7].

За часів незалежності України налічувалося шість Президентів України - Л. Кравчук, Л. Кучма, В. Ющенко, В. Янукович, П. Порошенко та В. Зеленський. Всі ці політичні лідери займали пост Президента на різних історичних та політичних етапах країни та всі вони різнилися за вмінням організовувати та займатися управлінською діяльність, а також будувати та підтримувати міжнародну політику. 
Слушно виражає свою позицію С. Бойко, який зазначає, що справжніми політичними лідерами $€$ ті, що сорормовані безпосередньо в політичній боротьбі. Нині в Україні не лише не зникають, а, навпаки, поглиблюються політичні проблеми, пов'язані з представництвом різних політичних партій, організацій, рухів, соціальних груп і різних класів у політичній владі. Ситуація в країні демонструє попит на політичних лідерів. За певних умов, у ролі лідерів іноді опиняються "політкустарі" з невисоким рівнем політичної та соціальної зрілості, політичної культури. В Україні змішана форма правління і лідер країни не поєднує у своїй особі функції президента і прем'єра [2, с. 95]. Попри це, нинішня політична ситуація $є$ парадоксальною для теорії розподілу влади, де законодавча, виконавча та судова повинні взаємодоповнювати та контролювати одна одну, однак на сьогодні влада $є$ монопольною та практично зосереджена в одних руках.

Д. Горбач виділив такі риси української правлячої політичної еліти та лідерів, як "політичний та економічний консерватизм, схильність до авторитарних і командно-адміністративних методів, кругова порука, кланові зобов'язання... Замість ринкової економіки маємо іiї мафіозно-олігархічний варіант. Реальна демократія та громадянське суспільство існують у зародкових формax" [4, с. 198].

До основних проблем української політичної еліти та лідерів, які впливають на ефективність їх діяльності $\epsilon$ :

- нечітка визначеність цілей та уявлень про напрям розвитку країни;

- розкол за ціннісними характеристиками: з одного боку - на тих, хто прагне розбудовувати державу на основі західних цивілізаційних демократичних цінностей суспільно-політичного, економічного і культурного розвитку, і з іншого боку - на тих, хто тяжіє до "керованої демократії", орієнтується на сильну державну владу, здатну виступати не лише в якості соціального арбітра, але й визначати напрямки реформ;

- українська еліта є фрагментованою, тобто такою, що володіє низьким рівнем структурної інтеграції, невеликою здатністю до консенсусу з приводу вибору та збереження основних суспільних цінностей; у той же час, елітні групи спроможні у складні, кризові моменти проявляти прагматизм і здатність до політичного компромісу;

- клановість, закритість формування, консервативність, регіональна прив'язаність політичних еліт;

— домінування "кумівства" та особистої відданості при призначенні на ключові державні посади;

- зрощення політичної і економічної еліти, часто - за визначальної ролі останньої;

- вплив політико-бізнесових угруповань в Україні $€$ потужнішим, ніж вплив партійних структур;

- діяльність політичних еліт і лідерів не реалізовує інтереси народу, відмова лідерів від відповідальності за результати свого управління державою, що, обумовлює до них недовіру народу;

- прихід до влади відбувається переважно не завдяки особистим досягненням чи здібностям, оціненим народом, а на хвилі недоліків і помилок опонентів, попередників [6, с. 36-37].

\section{ВИСНОВОК}

Політичні еліти та лідери України часу становлення незалежності фоормувалися у різний історичний час, який характеризувався різним рівнем економіки, політичної ситуації та суспільної напруги. Українська державність зароджувалася в екстремальних для державного управління умовах, відповідно перша сформована політична еліта була сумішшю комуністичних пережитків та демократичних начал. Оцінка довіри до влади демонструє несорормованість твердої суспільної позиції та стратегії формування політичної еліти та вибір політичного лідера.

Протягом еволюції політичної еліти та лідерів з початку незалежності України спостерігається як певні позитивні, так і негативні риси: до позитивних слід віднести - гендерна різноманіть у політичній еліті; належність до політичної еліти та лідерів молодих амбітних осіб; інклюзивність у більшості скликань Верховної Ради України, що демонструє відважність суспільства у пошуку оптимальної політичної моделі; аналіз відповідності результату роботи політичної еліти та лідерів на місцях цілям та інтересам суспільства, що допомагає формуванню політичної еліти та лідерів на державному рівні; до негативних рис відносимо - надмірна роль бізнес-лідерів у формуванні політичної еліти та лідерів; присутність "кумівства" у створенні державного апарату та призначення на державні посади; вибір політичної еліти та лідерів від протилежного за принципом "інший, аби не той", відповідно спостерігається ігнорування організаційних та управлінських здібностей у політичних лідерів та еліт; нездатність до консенсусу (що демонструє сучасна політична еліта та лідер); значний вплив олігархів на формування цілей діючої політичної еліти та лідерів, які не відповідають суспільним інтересам.

Література:

1. Антонова Н.Б. Теория и методология государственного управления / Н.Б. Антонова, Л.М. Захарова, Л.С. Вечер. 3-е изд., доп. - Минск: Акад. упр. при Президенте Респ. Беларусь, 2005. - 231 с.

2. Бойко С. Політичне лідерство в Україні: генезис і динаміка розвитку / С. Бойко. / / Політичний менеджмент. - 2011. - № 6. - С. 91-100.

3. Висоцький В. М. Політичні партії в процесі модернізації політичної системи України / В.М. Висоцький / / Проблеми становлення правової демократичної держави. -2014 . - № 4. - С. 3-6.

4. Горбач Д. Еволюція української політичної еліти: від партійних босів до босів великого бізнесу / Д. Горбач / / Наукові записки. - 2003. - Т. 22. - Ч. ІІ. C. $196-200$.

5. Кобець Ю.В. Якість політичної еліти України в контексті демократичних перетворень / Ю.В. Кобець, Т.Б. Мадрига / / Прикарпатський вісник НТШ. Думка. 2019. - № 4. - С. 70-80.

6. Корнієнко В.О. Ефективність політичного лідера: критерії та механізми реалізації в сучасній Україні / В.О. Корнієнко. - Вінниця: ВНТУ, 2009. - 140 с.

7. Крименюк О. Эволюция Рады: от Звягильского до Дубинского, как изменился наш парламент за 28 лет 2019 [Електронний ресурс] / О. Крименюк, М. Отт. - 
Режим доступу: https://www.liga.net/politics/articles /evolyutsiya-rady-ot-zvyagilskogo-do-dubinskogokak-izmenilsya-nash-parlament-za-28-let

8. Крючков В.А. Политическая элита: теоретический аспект / В.А. Крючков, А.К. Сковиков, О.Н. Титова / / Фундаментальные исследования. - 2013. - № 11. С. $1736-1740$.

9. Мандзій Л.С. Правляча політична еліта України: суть та етапи становлення: автореф. дис. на здобуття наук. ступеня канд. політ. наук: спец. 23.00.02 "політичні інститути та процеси" / Мандзій Л.С. - Львів, 2003. $15 \mathrm{c.}$

10. Морарь М.В. Політичне лідерство в сучасній Україні: проблеми становлення та розвитку / М.В. Морарь. // Грані. - 2017. - № 20. - С. 2-9.

11. Очирова В.М. Понятие "Политическая элита" в контексте научного знания / В.М. Очирова / / Вестник Забайкальского государственного университета. 2010. - № 6. - С. 68-73.

12. Рада. "Портрет" нового парламенту: якоюбуде Верховна Рада України 9-го скликання? [Електронний ресурс]. - Режим доступу до ресурсу: https://rada.oporaua.org/ novyny/novini/23591-portret-novogo-parlamentu-yakoyubude-verkhovna-rada-ukrajini-9-go-sklikannya

13. Федоров М. Нарцисизм посткомуністичної української еліти / М. Федоров / / Політична думка. - 2005. - № 3. - С. 20

14. Центр Разумкова. Оцінка громадянами діяльності влади, рівень довіри до соціальних інститутів та політиків, електоральні орієнтації громадян (лютий 2020 р. соціологія) [Електронний ресурс]. - Режим доступу до ресурсу: https://razumkov.org.ua/napriamky/ sotsiologichni-doslidzhennia /otsinka-gromadianamydiialnosti-vlady-riven-doviry-do-sotsialnykh-instytutiv-tapolitykiv-elektoralni-oriientatsii-gromadian-liutyi-2020r

15. Щедрова Г.П. Інституціональна дисфункція політичної еліти в Україні / Г.П. Щедрова. / / Збірник наукових праць "Гілея: науковий вісник". - 2017. № 120. - C. 238-242.

16. Garrido-Vergara L. Elites, political elites and social change in modern societies [Електронний ресурс] / L. Garrido-Vergara. - 2014. - Режим доступу до ресурсу: https://www.researchgate.net/publication / 273029631_Elites_political_elites_and_social_change_in_modern_societies

17. Higley J. Elite Theory in Political Sociology [Електронний ресурс] / J. Higley. - 2008. - Режим доступу: http://citeseerx.ist.psu.edu /viewdoc/download?doi=10.1.1.462.5495\&rep=rep $1 \&$ type=pdf).

References:

1. Antonova, N.B. (2005), Teoryya y metodolohyya hosudarstvennoho upravlenyya [Theory and methodology of public administration], Akad. upr. pry Prezydente Resp, Mynsk, Belarus'.

2. Boyko, S. (2011), "Political leadership in Ukraine: genesis and dynamics of development", Politychnyy menedzhment, vol. 6, pp. 91-100.

3. Vysots'kyy, V. M. (2014), "Political parties in the process of modernization of the political system of Ukraine", Problemy stanovlennya pravovoyi demokratychnoyi derzhavy. vol. 4, pp. 3-6.
4. Horbach, D. (2003), "The evolution of the Ukrainian political elite: from party bosses to big business bosses", Naukovi zapysky, vol. 22, pp. 196-200.

5. Kobets', Yu. V. (2019), "The quality of Ukraine's political elite in the context of democratic transformations", Prykarpat·s'kyy visnyk NTSh. Dumka, vol. 4, pp. $70-80$.

6. Korniyenko, V. O. (2009), Efektyvnist' politychnoho lidera: kryteriyi ta mekhanizmy realizatsiyi v suchasniy Ukrayini [The effectiveness of a political leader: criteria and mechanisms for implementation in modern Ukraine], VNTU, Vinnytsya, Ukraine.

7. Krymenyuk, O. (2019), "Evolution of Rada: from Zvyagilsky to Dubinsky, how our parliament has changed in 28 years", [Online], available at: https://www.liga.net/ politics / articles /evolyutsiya-rady-ot-zvyagilskogo-dodubinskogo-kak-izmenilsya-nash-parlament-za-28-let (Accessed 15 July 2021).

8. Kryuchkov, V. A., Skovykov, A. K. and Tytova, O. N. (2013), "Political elite: theoretical aspect", Fundamental'nye yssledovanyya, vol. 11, pp. 1736-1740.

9. Mandziy, L. S. (2003), "The ruling political elite of Ukraine: the essence and stages of formation", Ph.D, Political institutions and processes, L'viv, Ukraine.

10. Morar', M. V. (2017), "Political leadership in modern Ukraine: problems of formation and development", Hrani, vol. 20, pp. $2-9$.

11. Ochyrova, V. M. (2010), "The concept of "political elite" in the context of scientific knowledge", Vestnyk Zabaykal'skoho hosudarstvennoho unyversyteta, vol.6, pp. $68-73$.

12. Rada (2019), "Portrait of the new parliament: what will be the Verkhovna Rada of Ukraine of the 9th convocation?", [Online], available at: https://rada.oporaua.org/novyny / novini / 23591 -portret-novogoparlamentu-yakoyu-bude-verkhovna-rada-ukrajini-9-gosklikannya (Accessed 15 July 2021).

13. Fedorov, M. (2005), "Narcissism of the postcommunist Ukrainian elite", Politychna dumka, vol. 3, pp. 20.

14. Tsentr Razumkova (2020), "Citizens' assessment of government activities, level of trust in social institutions and politicians, electoral orientations of citizens (February 2020. sociology)". [Online], available at: https:// razumkov.org.ua/napriamky/sotsiologichni-doslidzhennia/otsinka-gromadianamy-diialnosti-vlady-rivendoviry-do-sotsialnykh-instytutiv-ta-politykiv-elektoralnioriientatsii-gromadian-liutyi-2020r (Accessed 15 July 2021).

15. Shchedrova, H. P. (2017), "Institutional dysfunction of the political elite in Ukraine ", Zbirnyk naukovykh prats' "Hileya: naukovyy visnyk", vol. 120, pp. 238-242.

16. Garrido-Vergara, L. (2014), "Elites, political elites and social change in modern societies", [Online], available at: https: / / www.researchgate.net/publication / 273029631_Elites_political_elites_and_social_change_in_modern_societies (Accessed $1 \overline{5}$ July 2021).

17. Higley, J. (2008), "Elite Theory in Political Sociology", [Online], available at:http://citeseerx.ist.psu.edu / viewdoc/download?doi=10.1.1.462.5495\&rep=rep1\&type=pdf) (Accessed 15 July 2021).

Стаття надійшла до редакиї 26.07.2021 p. 